\title{
Is India a Flailing State?: Detours on the Four Lane Highway to Modernization
}

\section{Citation}

Pritchett, Lant. 2009. Is India a Flailing State?: Detours on the Four Lane Highway to Modernization. HKS Faculty Research Working Paper Series RWP09-013, John F. Kennedy

School of Government, Harvard University.

\section{Published Version}

http://web.hks.harvard.edu/publications/workingpapers/citation.aspx?Publd=6599

\section{Permanent link}

http://nrs.harvard.edu/urn-3:HUL.InstRepos:4449106

\section{Terms of Use}

This article was downloaded from Harvard University's DASH repository, and is made available under the terms and conditions applicable to Other Posted Material, as set forth at http:// nrs.harvard.edu/urn-3:HUL.InstRepos:dash.current.terms-of-use\#LAA

\section{Share Your Story}

The Harvard community has made this article openly available.

Please share how this access benefits you. Submit a story.

Accessibility 


\title{
MARVARD Kennedy School JOHN F. KENNEDY SCHOOL OF GOVERNMENT
}

\author{
Faculty Research Working Papers Series
}

\author{
Is India a Flailing State? \\ Detours on the Four Lane Highway to Modernization
}

\author{
Lant Pritchett \\ John F. Kennedy School of Government - Harvard University
}

May 2009

RWP09-013

The views expressed in the HKS Faculty Research Working Paper Series are those of the author(s) and do not necessarily reflect those of the John F. Kennedy School of Government or of Harvard University. Faculty Research Working Papers have not undergone formal review and approval. Such papers are included in this series to elicit feedback and to encourage debate on important public policy challenges. Copyright belongs to the author(s). Papers may be downloaded for personal use only. 
May 13, 2009

\title{
Is India a Flailing State? Detours on the Four Lane Highway to Modernization ${ }^{1}$
}

\author{
Lant Pritchett \\ Harvard Kennedy School
}

\section{Introduction}

The premise of the recent Indian novel $Q \& A$ is that the hero, an uneducated working class waiter in a downscale restaurant, has won a billion rupees in a game show that requires answers to twelve questions of increasing difficulty ${ }^{2}$. The novel them weaves in and out of the hero's life with vignettes that reveal how he came to know the answers to each of the questions. The novel opens with the hero having won the game show but is being beaten by the police in a Mumbai police station as the producer of the game show, short on cash, has decided to pay-off the police to extract a false confession of cheating by the contestant rather than pay out the winnings. This is not remarked upon as unusual. As one reads the novel in each instance in which the hero's life intersects with agents of the government--he is treated with the same mix of venality and casual brutality. This is especially striking for two reasons. First, the bad behavior of the government is not a theme of the book nor is it ever remarked upon, rather these descriptions are there to provide verisimilitude of a real person’s life-

\footnotetext{
${ }^{1}$ This was originally prepared for a conference "Rule and Reform In the Giants" at Harvard University in November 2007. It was updated and revised in December 2008 and again lightly in May 2009.. Many thanks for the comments from the organizers, Devesh Kapur and Elizabeth Perry, which have been of great help, as well as from many others, including Adarsh Kumar, Joel Hellmann and John Briscoe.

${ }^{2}$ Entirely coincidentally, after this paper was written this novel was been made into the fantastically successful movie, Slumdog Millionaire released in late 2008.
} 
seem realistic and in-touch with the "true" India. Second, the novel was written, not an estranged radical, but by an active duty member of the Indian Foreign Service.

To understand the Indian state today one has to read fiction because non-fiction, the streams of government reports and commissions and documents produced by official agencies (including of those foreign agencies working with the government) are truly fiction. Because of the incredibly spectacular intelligence, cleverness, and competence of the top tiers of the Indian government—in particular the national services such as the Indian Administrative Service-it has managed to project the myth that India is just another regular modern state, with a growing economy, a democratic politics, a functional civil service, and making progress on social issues. For instance, ask any of them in an official setting about India's health system and you will get an elaborate and intriguing story about how many of this type of facility per that type of population, how each of those is staffed, what services they provide and the recent efforts to address their problems, like eliminating vacancies---all backed, if you want it, with data and reports. Travel to any part of India, but particularly the North—the BIMARU states ${ }^{3}$ —and you will realize that this description of India's actual health system, while it may serve as a organizing myth for the normative goals of the system, is, as a description of India's “health system”, a complete fiction.

India today is a fascinating mix. The economy is booming. Amazingly, after two decades of rapid growth performance that started in the 1980s, and that continued, after a brief interruption in 1991, after the economic reforms through the 1990s has accelerated again in the last few years (at least prior to the onset of the global crisis in 2008). India's

\footnotetext{
${ }^{3}$ An acronym for Bihar, Andhra Pradesh, Rajasthan, and Uttar Pradesh, though, as we will see this differ more quantitatively that qualitatively.
} 
democracy, by any measure, continues to astound, as despite all kinds of pressures, free and fair elections are held and control of the government changes hands regularly. Unlike all its neighbors, no one can argue that India is a failing or failed state.

The government of India and its personnel at the top levels in the elite institutions are impressive indeed. The Indian Supreme Court, the Indian Institutes of Technology, the All India Institute of Medical Sciences (AIIMS), India's nuclear program, to name a few, are all world class institutions. The IAS is full of officers who have passed an entrance examination and selection process that makes getting into Harvard look like a walk in the park. As a personal example, having lived and worked in India recently for the World Bank (from 2004 to 2007) my impression was that the World Bank, which tries to recruit staff of high quality with international expertise (and pays handsomely to do so), was by and large over-matched at nearly every level by their counter-parts at the corresponding levels in the government. The brains of the Indian state can formulate excellent policies and programs in nearly every domain. The head is so strong it can even remain in teetering control of the mountain of official paper work the maintenance of the appearance of the function of those programs it has designed requires (no one who has visited the offices of senior IAS officers have help but be awed at the amount of paperwork they handle—and simultaneously horrified by the amount they have to).

And yet, as I describe more fully below the capability of the Indian state to implement programs and policies is weak—and in many domains it is not obvious it is improving. In police, tax collection, education, health, power, water supply—in nearly every routine service—-there is rampant absenteeism, indifference, incompetence, and 
corruption. As this is true of even relatively routine services, even more so for more sophisticated ones like networked irrigation or groundwater management.

How does one reconcile the contradictions of a booming economy and democracy with world class elite institutions and yet chaotic conditions in service provision of the even the most rudimentary types? I argue that for India we need a new category ${ }^{4} . I$ argue that India is today a flailing state---a nation-state in which the head, that is the elite institutions at the national (and in some states) level remain sound and functional but that this head is no longer reliably connected via nerves and sinews to its own limbs. In many parts of India in many sectors, the everyday actions of the field level agents of the state-policemen, engineers, teachers, health workers-are increasingly beyond the control of the administration at the national or state level.

As this is part of a conference comparing India and China, I will risk a few comparisons, as at least the apparent contrast with China could not be more striking. In China one worries that, due to the lack of the processes of democratic representation the head of the state, while capable, is beyond the control of the citizens. Yet, at the same time one reads of local government officials being executed for corruption. Clearly the head has a strong interest in retaining control of the administrative apparatus of implementation. The Chinese state, while lacking all of the traditional apparatus of electoral democracy has nevertheless produced an effective state with strong capability for implementation at the ground level. As the paper presented by Whyte in the conference shows, this strong central controlled state capability, has the capacity for great

\footnotetext{
${ }^{4}$ Of course part and partial of all processes of description are classifying sub-types, for instance, while "democracy" is a type, there are a range of experiences that lead to sub-classifications-Collier and Levitsky (1997) in "Democracy with Adjectives" claim that 550 different sub-types of democracy have been proposed, which is pretty impressive, as it means it is a world with far less countries than types of democracy.
} 
and arbitrary evil—such as the Great Leap Forward and the Cultural Revolution—but has also managed to create the conditions for China’s sustained growth.

The first section outlines the four-fold structure of the transitions to modernization and suggests the term "flailing” state for those for which a primary failure is in administration. The second section gives evidence from a variety of sectors as to why India can be said to be a flailing state-with examples from a variety of publicly provided services: education, health, transfer programs, driver's licenses. The third section, the most speculative, presents conjectures about the underlying causes of the failures of administrative modernization to date and what the future might hold, in this section we return to some considerations of how society, state, and economy inter-link.

\section{I) What is a flailing state? Varieties of Deviations from Four-Fold Modernism}

The idea of “development” as an endeavor has been heavily driven by notions of a four-fold transformation that was called, in an earlier period unabashedly and without scare quotes, “modernization.” To become “developed” the newly colonized countries were expected to follow, roughly, an accelerated path along the same historical transformation of the countries_-almost exclusively Western in origin — who were then “modern.” Development was a four-fold transformation of economic, political, administrative, and social arrangements from “pre-modern” forms to “modern” institutional arrangements. I will briefly describe each dimension, including how the modern has moved to become in many instance “post-modern.”

Before I venture into this territory let me just issue three big caveats. First, much of what I am going to say is the kind of broad-brush descriptions that are entirely out of 
fashion, for many good reasons, with historians and social scientists. I am well aware that to every generalization I make there are a host of exceptions, divergences, and, one might say, counter-narratives. But if one wants to speak of where a notion and nation as complex as "India" is headed one has to pick some narrative thread and stick to it.

A second difficulty of this discussion is that the set of ideas called "modernization," the view that there is a single linear path of "development" has been intellectually completely discredited as a positive or descriptive notion. But this disappearance as a positive theory and part of respectable social science does not mean it has disappeared as a normative view, either popularly or organizationally. While no one today defends modernization, the overarching narrative of "development" as embodied in actions of all of the official agencies remains essentially modernization. As a program of action and normative goal there is no compelling alternative. So at one and the same time no one believes in modernization and everyone believes in modernization.

Third, as I articulate in the discussion, much of the world has moved on from the modern to the post-modern. As I will show, this enormously complicates any discussion as many of the ideas promoted as reactions to the success of modernization share similar vocabulary and hence a superficial resemblance to the pre-modern. I'll return to that later.

\section{I.a) The four-fold structure of the pre-modern, modern and post-modern}

Economic. The pre-modern economy is one characterized by most of the labor force engaged in agriculture and resource based activities, low levels of income, little industrialization and few people engaged in large scale enterprises of any kind. The economic transition to modern that I wish to identify is not just the shift in early 
industrialization from agriculture to factories but the equally important later shift to the large scale industrial corporations with professional management. That is I am thinking not of the Industrial Revolution but the much later the rise of the "modern" economy as described in Chandler's magnificent Scale and Scope. This transition created large scale organizations who emphasized the benefits of coordination and economies of scale achievable with hierarchical management. I am regarding as the paradigm of a "modern" economy not the transition from mercantilism to market but the late $19^{\text {th }} /$ early $20^{\text {th }}$ century transition to "managerial capitalism” (Chandler, 1977) and the rise of the multidivisional firm as described by early practitioners such as Barnard's Functions of the Executive and Sloan's My Years with General Motors. This can be contrasted with an emerging "post-modern" economy in which the gains to flexibility and creativity exceed those of coordination and scale (Roberts 2004).

Political. Any description I can give of the political transition to the modern will be inadequate, particularly when compared to recent magisterial expositions such as Bayly's Birth of the Modern World, but to my mind it has two key, related elements. One element is the transition of the proto-typical relation between the ruled and the ruler(s) from subject to citizen. To caricature, a pre-modern conception was that the people living in a territory were chattel of the state, who could be transferred from one ruler to another. The modern conception is that the citizens collectively constitute the state which exists legitimately only as an expression of their will.

A second foundation of the modern political state is the expansion, in fits and starts over time, towards the idea of universal equal treatment of all citizens by the state- the extension of the franchise being an obvious, but not the only example. This 
dates the emergence of "modern" polities not into the $18^{\text {th }}$ century or early $19^{\text {th }}$ centuries (by which times many countries unambiguously had some form of "democracy”) but rather into the late $19^{\text {th }} /$ early $20^{\text {th }}$ centuries, arriving only definitively and irreversibly after the debacle of World War I saw the definitive collapse of royalty as an alternative. Of course, the triumph of this notion in practice took into our lifetimes (e.g. AfricanAmericans in the USA) — which again stresses that all categories are not hard and fast but hugely permeable and co-exist.

Administrative. The "modern" administration is the civil service bureaucracy, as is typified say, by the post office. The description by Max Weber of this new type of organization is justifiably called a Weberian bureaucracy. The central defining features are merit based recruitment, tenure in office not linked to personal or political patron, hierarchical structures, with the agents of the organization tasked with performing through an impersonal application of rules. Since the course of administrative modernism is the main subject I will elaborate this more fully below.

Social. The other three modernizations were expected to go hand in hand with a social modernization, particularly with regard to the primacy of the needed economic, political and administrative modernizations over social ties. That is, modern economic transactions were expected to depend on arms-length exchanges that were not (necessarily) embedded in other social relationships—either lateral or vertical (e.g. free labor). The rise of the modern polity similarly depended on the construction of an “imagined community" (Anderson 1983) of the nation for which an individual was expected to feel some solidarity and ascriptive identity. This in particular in the 
experience of the West required overcoming religious affiliation and regional sentiment in favor of the nation-state.

The triumph of the impersonal application of the rules that treated all citizens as equally placed required that this relationship between human beings was socially legitimate—which required overcoming both vertical allegiances (e.g. to patrons), vertical entitlements to superior treatment, and also horizontal attachments to treat members of one's own group (by ethnicity, religion, political persuasion) as superior in fulfilling their tasks.

\begin{tabular}{|c|c|c|c|}
\hline & \begin{tabular}{|l|} 
Pre-modern \\
\end{tabular} & Modern & Post-Modern \\
\hline Economic & $\begin{array}{l}\text { Agricultural, small } \\
\text { scale, face to face } \\
\text { transactions }\end{array}$ & $\begin{array}{l}\text { Large scale } \\
\text { corporations, } \\
\text { creation of } \\
\text { institutions for large } \\
\text { scale impersonal } \\
\text { transactions }\end{array}$ & $\begin{array}{l}\text { Move to production } \\
\text { of immaterial value, } \\
\text { near zero } \\
\text { transaction costs, } \\
\text { product } \\
\text { differentiation }\end{array}$ \\
\hline Political & $\begin{array}{l}\text { Fractured, } \\
\text { personalistic, } \\
\text { subjects not citizens }\end{array}$ & $\begin{array}{l}\text { Citizens control } \\
\text { nation-state, equal } \\
\text { treatment of all } \\
\text { citizens }\end{array}$ & $\begin{array}{l}\text { Deeper levels of } \\
\text { participation, more } \\
\text { local }\end{array}$ \\
\hline Administrative & $\begin{array}{l}\text { Personalistic, } \\
\text { appendage of office, } \\
\text { patronage based. }\end{array}$ & $\begin{array}{l}\text { Civil service } \\
\text { bureaucracies (merit } \\
\text { based recruitment, } \\
\text { hierarchical), } \\
\text { impersonal } \\
\text { applications of rules }\end{array}$ & $\begin{array}{l}\text { Greater civic } \\
\text { engagement, "Re- } \\
\text { inventing" } \\
\text { government, more } \\
\text { flexibility, the new } \\
\text { public sector } \\
\text { management } \\
\text { (autonomy for } \\
\text { accountability) }\end{array}$ \\
\hline Social & $\begin{array}{l}\text { Small scale (kith } \\
\text { and kin) local } \\
\text { affiliations plus } \\
\text { regional, ethnic and } \\
\text { sectarian }\end{array}$ & $\begin{array}{l}\text { Nationalism as a } \\
\text { primary social } \\
\text { affiliation }\end{array}$ & $\begin{array}{l}\text { Proliferation of } \\
\text { identities, micro- } \\
\text { communities, } \\
\text { globalization }\end{array}$ \\
\hline
\end{tabular}


The essence of modernization as development was a narrative that was both positive and normative both in retrospect and prospect. The dominant narrative told as history was the rise of the West, in which all the existing countries went through a mostly similar set of stages to arrive at the "modern" with roughly similar features—industrial economies, liberal multi-party democracies with universal franchise, civil service bureaucracies as the main agents of implementation, and "nationalism" as a social force. Moreover, this was normatively regarded as a "rise" of the West. At its most blatant, the history of administrative modernization in the USA was called the "Progressive" movement-hard to argue there was value neutrality. Again, the dominant narrative was that all four of these transitions were "progress" and progress that was not just the inevitable hand of history but also good.

It is of course impossible in the current, post-Foucault, era in which nearly every aspect of the naïve version of modernization has been attacked as simplistic and inaccurate historically (both in its assertions of the lack of modern features in "premodern" societies and its assertion of the irrelevance of pre-modern features in "modern" societies ), revealed as a deliberately perpetuated misreading of current realities (e.g. Ferguson 1994, Scott 1998) deconstructed as self-legitimating discourse to justify power relationships, to talk of "modernization" in its old normative sense, I make no attempt to resurrect modernization as a normative nor prescriptive approach, rather the reader should interpret all descriptions as relative to the notions of modernization, but stripped of normative implication. So a "failing" state means one that has failed relative to the expectations of the path expected under modernization, but is not to be interpreted normatively. 


\section{I.b) Deviations from the four fold path: Distinguishing Failing from Flailing}

The concept of a "failing state" has achieved wide currency, including, like every concept these days of any heft, its own index (published by Foreign Policy and the Fund for Peace). Their “failing state” index combines a dozen indicators (four social, two economic, and six political) to come up with an omnibus ranking with Sudan, Iraq and Somalia at the bottom and, naturally, the Nordics, Sweden, Finland, Norway at the top. While it is obvious that there is no hard and fast definition for the concept of a "failing state" the index is plausible as it combines a variety of types of failure into a single index.

On this score India looks very good, especially compared to its neighbors. Out of the 177 countries ranked in 2007 India was $110^{\text {th }}$ (better than 109 other countries, low rank means more failed). In contrast Pakistan was the $12^{\text {th }}$ most failed state, Bangladesh $16^{\text {th }}$, Nepal $21^{\text {st }}$, Sri Lanka $25^{\text {th }}$ and Afghanistan was $8^{\text {th }}$. But too rapid a pressure to aggregate ignores Tolstoy’s wise observation that “All happy families are alike, every unhappy family is unhappy in its own way.” While there are obvious cases in which all four dimensions of the transition to a modern state have failed, there are also different types of failures. Some countries, like Cuba, have little economic progress but do have strong administrative systems, at least in some dimensions. Other countries, like Bangladesh or Pakistan have weak democracies and weak administrative systems, but have had quite robust economic growth. 


\begin{tabular}{|c|c|c|c|c|c|c|}
\hline $\begin{array}{l}\text { Economic } \\
\text { (rapid } \\
\text { sustained } \\
\text { growth) }\end{array}$ & Fail & Fail & Succeed & Fail & Succeed & Succeed \\
\hline $\begin{array}{l}\text { Political } \\
\text { (mechanisms } \\
\text { of political } \\
\text { expression) }\end{array}$ & Fail & Fail & Fail & Succeed & Succeed & Succeed \\
\hline $\begin{array}{l}\text { Administrative } \\
\text { (Capable } \\
\text { bureaucracies) }\end{array}$ & Fail & Succeed & Succeed & Succeed & Succeed & $\begin{array}{l}\text { Mixed } \\
\text { (Failure } \\
\text { concentrated in } \\
\text { implementation) }\end{array}$ \\
\hline $\begin{array}{l}\text { Social } \\
\text { (Nation-state } \\
\text { affiliation) } \\
\end{array}$ & Fail & Succeed & Succeed & Succeed & Succeed & Mixed \\
\hline $\begin{array}{l}\text { Proposed } \\
\text { Name }\end{array}$ & $\begin{array}{l}\text { Failed } \\
\text { States }\end{array}$ & $\begin{array}{l}\text { Pre-reform } \\
\text { communist }\end{array}$ & $\begin{array}{l}\text { Market } \\
\text { Authoritarian }\end{array}$ & $\begin{array}{l}\text { Successful } \\
\text { Stagnaters }\end{array}$ & Stars & Flailing \\
\hline Examples? & $\begin{array}{l}\text { Somalia, } \\
\text { DRC, } \\
\text { Nepal, } \\
\text { Burma, } \\
\text { North } \\
\text { Korea }\end{array}$ & $\begin{array}{l}\text { Cuba, China } \\
\text { (pre-78), } \\
\text { Vietnam } \\
\text { (pre-86) }\end{array}$ & $\begin{array}{l}\text { Indonesia } \\
\text { (1967-1998), } \\
\text { Singapore, } \\
\text { Malaysia, } \\
\text { China, } \\
\text { Vietnam, }\end{array}$ & Costa Rica & $\begin{array}{l}\text { Korea, } \\
\text { Taiwan }\end{array}$ & India? \\
\hline
\end{tabular}

The fascinating aspect of India is that, while it scores far above its neighbors in measures of democracy or human rights or absence of conflict-it does not outperform them in measures of human development outcomes and is side by side in measures of governmental effectiveness or (negatively) on corruption. Three quick examples of this phenomenon in cross-national rankings will suffice before moving to the more revealing and interesting India specific detail ${ }^{5}$.

First, two of the components of the failed states index on which countries are ranked from 1 (best) to 10 (worst) are the "Progressive Deterioration of Public Services” and "Suspension or Arbitrary Application of the Rule of Law and Widespread Violation

\footnotetext{
${ }^{5}$ These comparisons suppress the obvious fact that India is both huge and diverse. The typical Indian state larger than most countries in the world and the variation within India of many indicators, such as literacy, infant mortality, gender ratios, infrastructure, is as large as variation across many countries. Some wonder whether for most purposes "India” can be considered a useful way of aggregating data.
} 
of Human Rights.” On the latter, India scores substantially better than any of its neighbors with a score of 5.4 while on the "Progressive Deterioration of Public Services" India ranks worse than Sri Lanka or Nepal and only modestly better than Bangladesh and Pakistan.

\begin{tabular}{|l|c|c|c|c|}
\hline \multicolumn{5}{|l|}{$\begin{array}{l}\text { Table 3: In a ranking of "failing” states India scores by far the best in its region on } \\
\text { rule of law and human rights, but in the middle of the pack in services }\end{array}$} \\
\hline & $\begin{array}{c}\text { Suspension of Rule of Law, } \\
\text { Violation of Human Rights } \\
\text { (1-10, 1 worst) }\end{array}$ & $\begin{array}{c}\text { Progressive Deterioration of } \\
\text { Public Services } \\
(1-10,1 \text { worst) }\end{array}$ \\
\hline India & $\begin{array}{c}\text { Raw Score } \\
\text { Compantage } \\
\text { India }\end{array}$ & Raw Score & $\begin{array}{c}\text { Disadvantage } \\
\text { Compared to } \\
\text { India }\end{array}$ \\
\hline Sri Lanka & 7.4 & $38.9 \%$ & 6.5 & $-3.0 \%$ \\
\hline Bangladesh & 7.8 & $44.4 \%$ & 6.6 & $-1.5 \%$ \\
\hline Pakistan & 8.7 & $61.1 \%$ & 7.1 & $6.0 \%$ \\
\hline Nepal & 8.8 & $63.0 \%$ & 7.4 & $10.4 \%$ \\
\hline Source: Failed State Index, http://www.fundforpeace.org/web/ \\
\hline
\end{tabular}

A second comparison is to compare a standard measure of "democracy" which is a measure of the "polity" which subtracts from a 1 to 10 measure of "democracy" a 1 to 10 measure of "autocracy" (recognizing that these can co-exist in various measures) so that complete democracy is a polity score of 10 and complete autocracy a polity score of negative 10 (e.g. Turkmenistan, North Korea are -9 in 2006). By these measures what is striking about India is not only that it is democratic today, but that it has been (almost) continuously democratic since independence and so has very little variability in the score in its democracy score. In contrast, most of its other South Asian neighbors have had mixed histories of military interventions, widespread civil conflicts, and autocratic 
regimes - and hence show both low average and highly volatile democracy scores. And yet, if we compare these same countries on measures of an output that is universally acknowledged as desirable and primarily a governmental responsibility to ensure, like child immunizations, then not only does India lag dramatically but has shown retrogression. Whereas both India and Bangladesh had DPT3 immunization coverage of around 70 percent in 1995 by 2006 this had risen to 88 percent in Bangladesh but fallen to 55 percent in India. This “democracy/performance” puzzle is also revealed to some extent in a general indicator of well-being like infant mortality (which also, since it is influenced by income, distribution of income, maternal education, nutrition and government services is taken an omnibus non-money metric measure of performance). India is superior to only Pakistan in both the level of infant mortality and in the pace of reduction since 1980 .

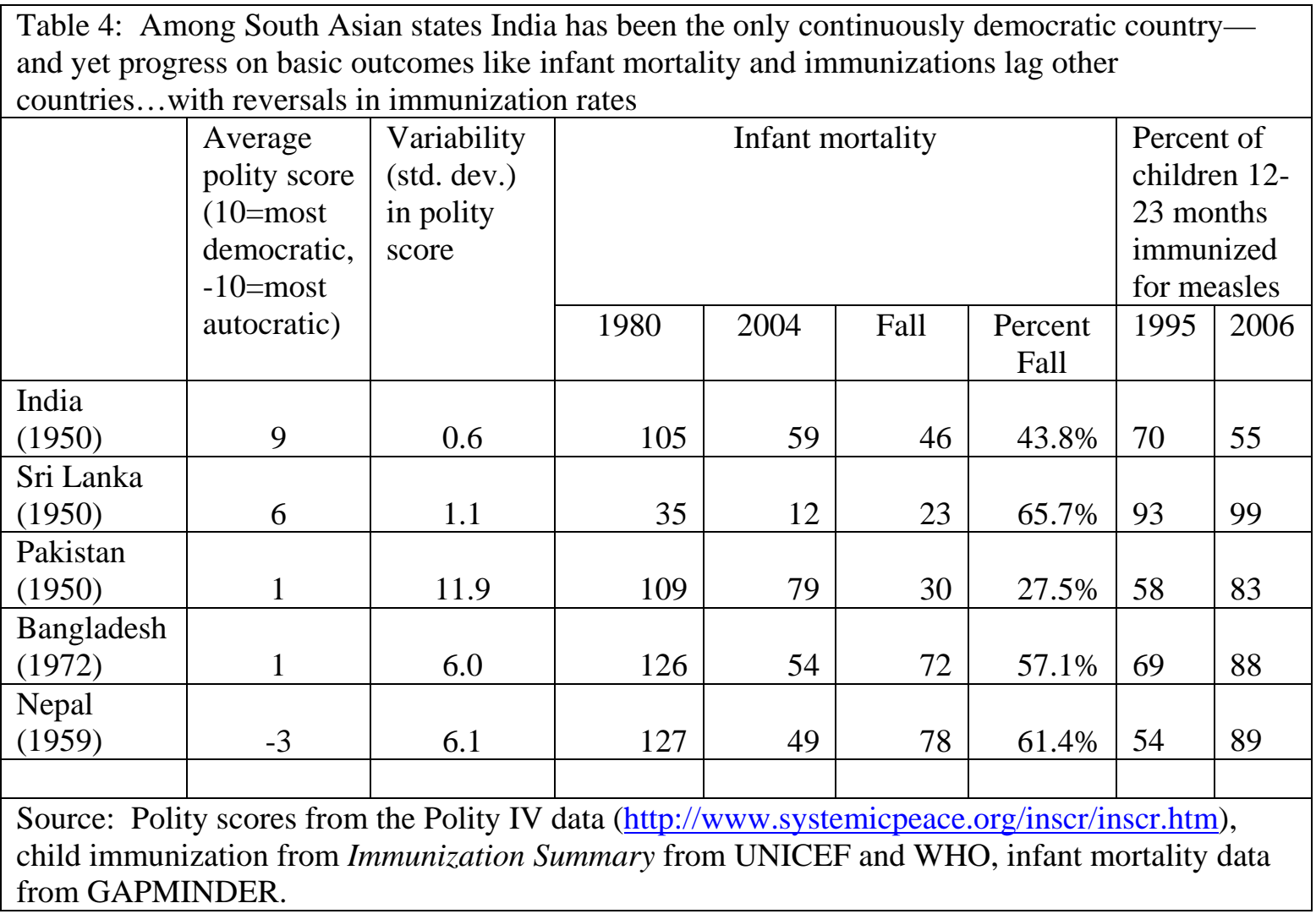


A final way of posing the difference between a failing state in an economic or political dimension and a flailing state is to compare India to other countries with similar track records on democracy in their performance in controlling corruption. Table 6 compares two indicators of corruption for those non-OECD countries that were as “democratic” as India and has achieved a polity score of 9 or better continuously since 2000. Compared to these countries there is a big gap between countries like Chile, Taiwan, South Africa and Costa Rica (all with scores above 5.0) and India, which has rankings with countries like Jamaica and Panama.

\begin{tabular}{|c|c|c|c|}
\hline Country & $\begin{array}{l}\text { Polity Score in } \\
2006\end{array}$ & $\begin{array}{l}\text { Transparency } \\
\text { International } \\
\text { Corruption } \\
\text { Perceptions Index } \\
2007\end{array}$ & $\begin{array}{l}\text { Control of Corruption } \\
\text { (percentile rank among } \\
\text { countries) }\end{array}$ \\
\hline Chile & 10 & 7.0 & 89.8 \\
\hline Taiwan & 9 & 5.7 & 70.4 \\
\hline Botswana & 9 & 5.4 & 78.2 \\
\hline South Africa & 9 & 5.1 & 70.9 \\
\hline Costa Rica & 10 & 5.0 & 67.0 \\
\hline India & 9 & 3.5 & 52.9 \\
\hline Jamaica & 9 & 3.3 & 44.5 \\
\hline Panama & 9 & 3.2 & 49.5 \\
\hline Trinidad & 10 & 3.1 & 54.9 \\
\hline
\end{tabular}

Polity scores from the Polity IV data (http://www.systemicpeace.org/inscr/inscr.htm), CPI from Transparency International, Control of Corruption from

While one doesn't want to place too much weight on any given cross-national comparison, and one can quibble endlessly over whether the broad concepts lie “democracy” and "corruption” can be precisely measured, there are a couple of items on which there is clarity. First, India is not a failing state. It is not failing economically. It is not failing to maintain the basics of law and order and security—with some (worrisome 
and growing) exceptions with Naxalite areas and movements on the edges of India--the state actively maintains order. It is certainly not failing to maintain democracy, while there are certainly pockets of trouble, by and large India has maintains all of the features of a modern democratic polity: electoral democracy, an active parliament with constraints on the executive, respect for human rights, a free press, an independent judiciary. But it is equally clear that India is not an entirely successful state either-its performance in basic services lags even compared to its region.

I propose to label the inability to maintain sufficient control of the administrative apparatus in order to effectively deliver services through the government in spite of democracy and strong capability at the state level a "flailing” state. I turn to greater description in the next section with speculation on diagnosis and prospects in the final section.

\section{II) The Weakness of Administrative Modernism}

I want to supplement the fiction of the introduction and the crude cross-national comparisons of aggregate indicators with specific indications of what I mean by the failure of the transition to administrative modernism in India. The essence of administrative modernism is that civil service agents of the state carry out their prescribed functions according to the organizational processes and procedures and irrespective of politics, personal characteristics, or pecuniary motivations. This, while certainly it happens, has ceased to be the norm in large parts of India in which the civil service, from top to bottom has been politicized, personalized, and corrupted. I could give dozens of examples, including from government reports. In fact, one indication that 
the Indian state is flailing and but not failing is that the governmental audit offices still produce reports detailing the flaws in program implementation. But I will focus on three relatively recent studies that have examined particular aspects of the flailing state: attendance, effort, and corruption.

\section{II.a) Attendance of nurses in Rajasthan}

\section{0 percent of success is just showing up \\ Woody Allen}

A group of academics have been working with Seva Mandir, a local NGO active in Rajasthan, to define and examine using rigorous controlled experimental methods innovations that would benefit the poorer rural population of Rajasthan. Their initial investigations revealed that health issues were important and a extended careful tracking study of the attendance of the medical staff at local level facilities (sub-centers and PHCs) confirmed what earlier studies had shown (Chowdhury, et al 2006) — that attendance on any given day was only around one-half (Banerjee, Deaton, Duflo 2004). That is, one half of the staff appointed and being paid to run these facilities were present during the facilities stated hours of operation. This of course led most people to seek health care elsewhere, with the richer population mostly using other private providers and with the poor resorting to what are, euphemistically called "less than fully qualified providers” which range from traditional healers (bhopas) to "Bengali doctors" (individuals with some literacy who give injections and dispense drugs).

To address this problem of staff absenteeism the NGO worked with the government to devise a scheme to improve attendance that would be implemented as the government moved to put augment the existing staff by placing an additional auxiliary 
nurse midwife (ANM) into each clinic. In this program the ANMs had to keep strict track of their time present by using a time clock that would date stamp their attendance records. The NGO would double check these official attendance records with spot "ground truthing" in anticipation of cheating. The proposed incentive for attendance was that any ANM who missed more than one half of the assigned days without a legitimate excuse (such as illness, authorized other duties, off site training, etc.) would have their pay docked. Moreover, in order to reduce complaints that the ANMs lack of presence at the clinic was the result of other duties the government declared that one day would be the "monitored" day on which ANMs would have no other duties. It was hoped this intervention would raise attendance and hence raise facility utilization and services. So that one could rigorously examine the impact of this program it was implemented in "treatment" areas and not implemented in "control” areas.

The reader can get some idea of the results from the title of the resulting study: Putting a band-aid on a corpse: Incentives for Nurses in the Indian Public Health Care System. Figure 1 (figure 3 of the paper this is taken from) shows the key results, which track the difference in attendance between the treatment and control clinics. What appears to have been the case is that the launch of the program initially raised attendance in both treatment and control areas (perhaps as the result of "Hawthorne" effects of being observed), then attendance in the control areas (in which no additional monitoring was introduced and no incentives were given) fell back to presumably baseline levels. More interestingly, in spite of the additional observation, in spite of the incentives, in spite of the monitoring, in spite of the fact these were "additional" ANMs (and so might have been not accustomed to poor performance), in spite of the introduction of "monitored" 
days attendance in the "treatment" areas fall so that by July of 2007 the presence rates on the monitored days were almost exactly the same- - both around one-third.

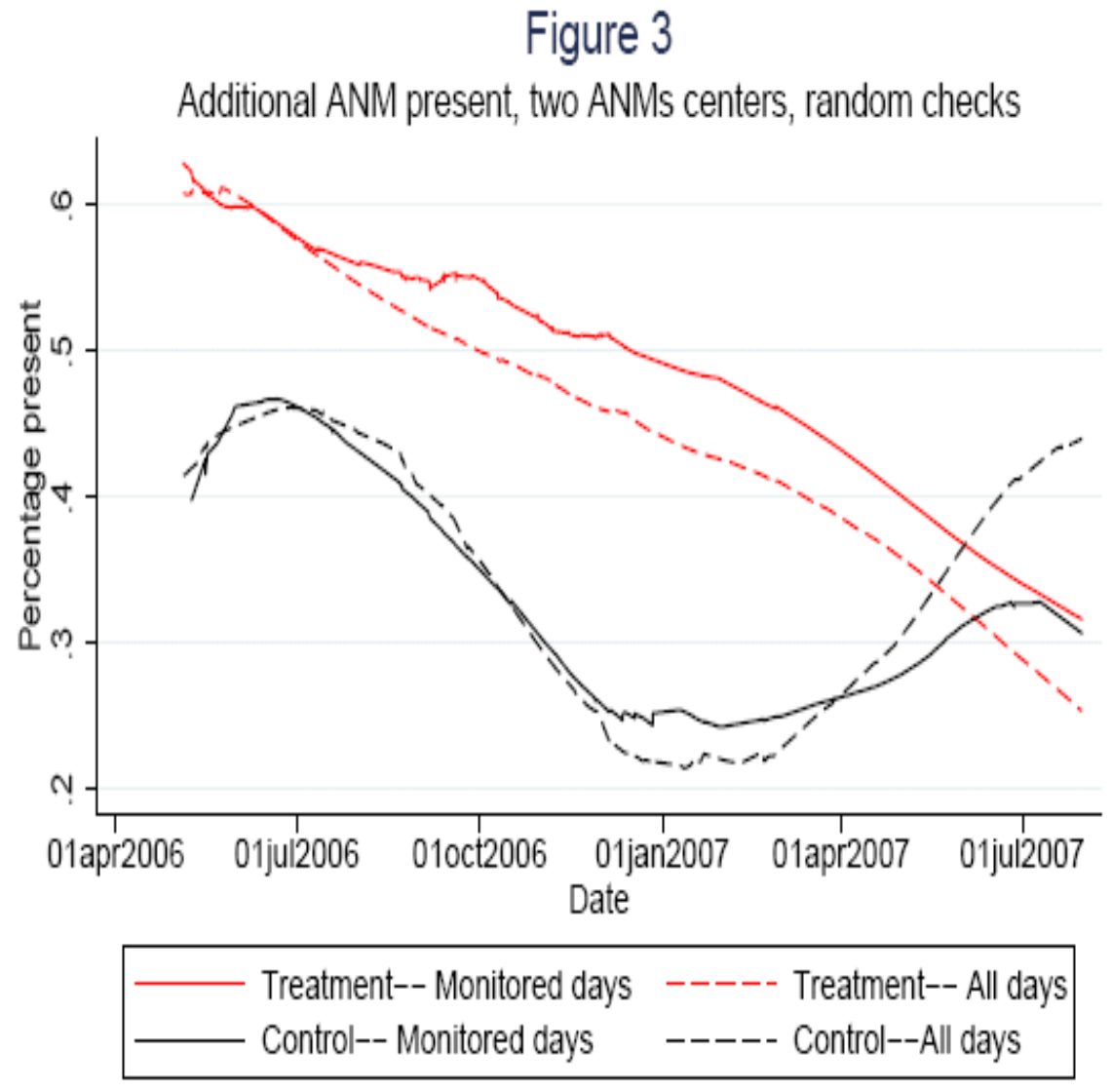

Source: Banerjee, Duflo and Glennerster, 2007

The comedian Woody Allen once quipped that 80 percent of life is just showing up. When workers do not even show up this is an indication of a serious inability of the administrative system to control the behavior of government employees—how can it induce the correct behavior in the job when they cannot even assure attendance. Feasible attendance rates (given illness, other duties, emergencies, etc.) are almost certainly more than 90 percent. If absence rates are above 10 percent an organization has a management problem, if they are more than 15 percent it has a management crisis. But when one-half to two-third of workers do not show up-that reflects not the management of a particular 
school or district or agency, but rather a more severe system crisis. And when these attendance rates are impervious to well-designed attempts to raise them this suggests the systemic issues run deeper than merely organizational or incentive design ${ }^{6}$. I am of course aware of the dangers of extrapolating from a single district in a single state, but Rajasthan is unfortunately not atypical of attendance rates around India, I am only focusing on this particularly study not because it is particularly egregious or atypical but because of the new information about the ability (or not) to alter these attendance rates.

\section{II.b) Doctors in Delhi}

A second example of the inability for the public sector to induce the actions needed to implement policy comes from a study of the qualifications and practices of individuals providing heath care in Delhi. This study chose a random sample of the providers of medical care in Delhi that people actually use, stratified to reflect different neighborhoods (poor, middle and rich), different sector (public versus private) and different facilities (clinics versus hospitals). Note that since the sample was drawn from the "medical" care providers that people reported using this is not a study of "doctors" as it includes many "less than fully qualified" individuals who are providing health care. The most interesting aspect of the study for my purposes is that the study independently measured the competence and the practices of providers.

In order to assess competence the researchers used vignettes in which providers were presented with hypothetical "patients" who would answer questions as if they had the disease for five common medical conditions to see if the providers could successfully diagnose and recommend treatment appropriate to these five conditions. For instance, for

\footnotetext{
${ }^{6}$ This is in contrast to an effort to use date stamped cameras to improve attendance in NGO run schools which reduced absence rates from 42 to 21 percent, suggesting that in the context of these NGO schools incentives did work, impressively (Duflo, Hanna and Ryan 2008).
} 
TB the hypothetical patient (and the provider knew the patient was hypothetical) would present with a persistent cough, if the provider asked about sputum and blood in the sputum the patient would answer appropriately. If the provider recommended a chest Xray the patient had one prepared that would be given to the provider to interpret. The researchers combined the likelihood of the provider correctly responding to the five vignettes to create an index of competence or theoretical knowledge. Subsequently, the researchers visited the providers premises to observe for an entire day the providers practice — what questions did they ask, what tests did they perform, what did they recommend on the basis of those tests. From these observations they created an index of provider "effort."

The truly unique feature of this study is that one can compare the various providers' clinical competence (the blue diamonds), what they know in theory they should do, and what they actually do in practice (the red triangles). Figure 2 shows the results on those two dimensions, each summarized as a normalized (mean zero, unit standard deviation) index, stratified by whether or not the provider is in the public or private sector and the neighborhood of the facility. The results for the government lower level clinics, the Primary Health Center (PHC), are striking. For instance, in the middle tier neighborhoods in Delhi the PHC providers (all of whom are MBBS trained doctors) have higher clinical competence than do the private providers. But when one compares the effort in practice, there is a huge difference — the effort of private providers exceeds their competence score while that of the public providers is far lower ${ }^{7}$. The same is true

\footnotetext{
$7 \quad$ This is not meant as praise of private sector health care, after all, what "more effort" by practitioners without adequate training means they do more to make the patient happy-but that often included over-prescribing medications that are worthless or even contra-indicated in order to give their customers/patients they are doing something.
} 
in all three types of neighborhood, the effort in practice of public providers in clinics is far lower than their clinical competence (by more than a full unit of the index) while in each case the private providers have more effort than competence.

Figure 2: Comparing the competence and effort of public and private providers of health care services in New Delhi reveals a massive effort deficit

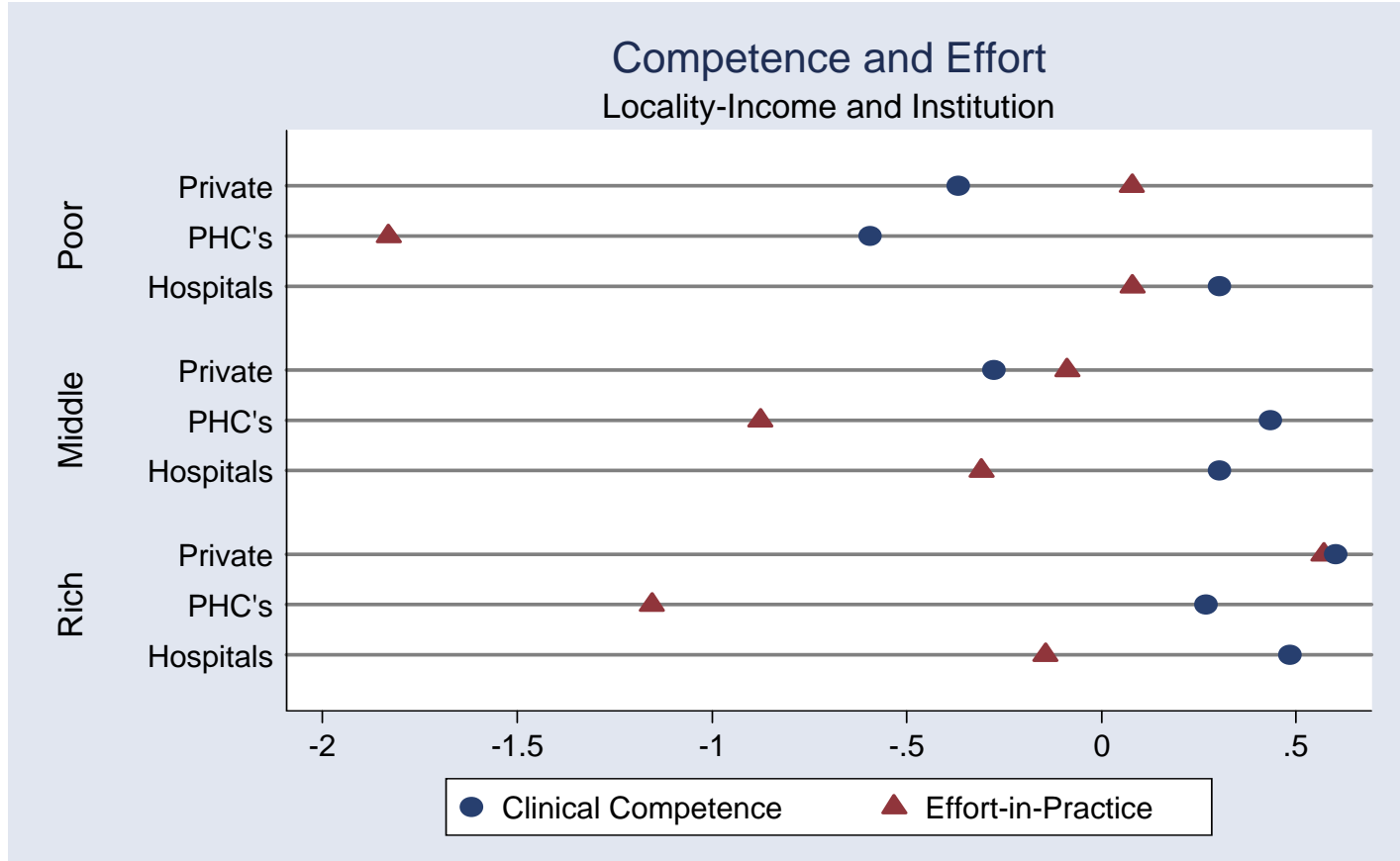

Source: Das and Hammer 2006.

All of the PHC effort-in-practice scores are at or below negative 1. At that level of effort the median (typical) patient/provider interaction is 2,1,0: it lasts 2 minutes, there is one question asked and no "physical exams" (which includes, pulse, blood pressure, temperature). The important point is that the providers have the clinical competence to know that they are not providing quality treatment. This suggests that, in addition to the 
difficulties of absences, even when present the existing system of administration are not able to elicit high quality effort from providers ${ }^{8}$.

\section{II.c) Driver's Licenses in Delhi}

For my friends, anything; for my enemies, the law.

Oscar Benevides, President of Peru, 1933-1940

A third recent study also uses the method of a controlled experiment, this time in obtaining a driver's license in Delhi to get more insight into the organization and consequences of corruption of routine administrative tasks. The study solicited individuals who were about to obtain a driver's license to participate in an experiment and divided those amenable to participation in the study into three groups. The comparison group was given no treatment at all while there were two "treatment" groups. One treatment consisted of simply paying a bonus to individuals who obtained a license more rapidly. Another treatment group received free driving instruction to improve their performance on the driving exam. The individuals then were left to go about getting a license. The study then followed the individuals to see (i) whether they had obtained a license, (ii) whether they had hired an agent to assist them in obtaining a license, (iii) whether or not they had complied with all of the stipulated procedures for obtaining a license, and (iv) the study have the driving competence of each person who obtained a license assessed by an independent driving instruction firm.

Some of the most important results of the study come from just examining the comparison group, although these results confirm what any resident of Delhi intuitively

\footnotetext{
${ }^{8}$ And we are deliberately focusing on the PHC level, that is not typically as busy as the hospitals. That is, some feel the public sector doctors are stretched by the number of patients and simply cannot do what is needed in the time available, while these may be true at the premiere facilities, the research did not suggest this was true at the typical PHC.
} 
knows. First, even in the comparison group that had no bonus for rapid acquisition of a license many hired an agent to facilitate the process. The hiring of the agent did in fact accelerate the process, in particular by almost completely subverting the driving test. Of those in the comparison group that hired an agent only 12 percent took the driving exam compared to 94 percent of those who did not. Many of those who did take the driving examination failed the exam. The primary response of those who failed the exam was not, as you might guess to receive more driving instruction but rather, in the next round of application, hire an agent (which, one suspects, was the point of failing them). In administering the independent assessment the driving firm classified as "automatic failures” those who could not answer some very basic questions about the operation of an automobile sufficient to make the driving instructors feel safe in actually administering the exam. Of those in the comparison group who hired an agent (and hence almost universally avoided the driving test) 69 percent were automatic failures in the independent test. The point is that this agent-payment induced informal "waiving" of the driving test is not benign, in that it is merely "speed money" to accelerate a license for those who are competent drivers, but rather the failure to comply with regulations actually subverts the public policy purpose of having a driving license.

The experimental treatment confirmed these results of the comparison group and showed that by increasing incentives to individuals for a rapid license the process was easily subverted. In the treatment group paid for getting a license more rapidly they were (a) more likely to hire an agent and (b) were 18 percentage points more likely to both obtain a license and fail an independent driving test than the control group. Perhaps not 
surprisingly, the treatment group who was provided training to improving driving skills was no more likely to obtain a license. .

The importance of this study is not documenting the existence of corruption in obtaining a driver's license (which is obvious to anyone who has a driver's license) but rather three features of that corruption. First, it is fully institutionalized. Almost no one reported paying bribes directly to the public sector employee; rather they paid fees to intermediaries. This suggests that the corruption is highly organized, with the take from the corruption divided amongst the various actors and is not the behavior of a few "rogue" instructors who elicit payments retail. Rather, the de jure process no longer has any real claim on the behavior of the agents of the state, who are following a different $d e$ facto set of procedures. Second, the de facto behavior of the agents of the state in granting licenses deliberately subverts what is intended as a step in the process intended to ensure the purpose of the regulation. That is, if the paying of agents subverted some element of the regulation that seemed trivial or pointless with regard to traffic safety (say, verifying residence) one might think this deviation was harmless, part of the normal adaptation of by-the-book regulation to reality in any "street level bureaucracy." But the step that was subverted, the driving examination, is precisely the one intended to assess driver competence. Assessments of driver competence as part of licensing may or may not be truly effective in increasing traffic safety, but this is surely its intent and it is this that is avoided by paying agents. Third, it does appear that this subversion of assessments of driving competence does allow unqualified drivers onto the road. The corruption does not merely accelerate outcomes but changes them. 
While these are isolated examples drawn from limited activities and places, they are consistent with the cross-national evidence, the nation-wide evidence on absenteeism, data on corruption and leakage, and surveys of citizen satisfaction (Paul et al), and with everyday experience of Indians ${ }^{9}$ (and, not coincidentally, modern fiction). Moreover, they illustrate key points about the depth and intractability of the problems with the failures of administrative modernism:

$>$ even routine expectations of government employees, like attendance, are resistant to reform, even reform championed by the "head" (e.g. the local district IAS officers) and supported by effective NGOs,

$>$ Increased competence is not incompatible with exerting effort to perform jobs satisfactorily,

$>$ Corruption and deviation of the de facto practice from de jure regulations have become not just prevalent, but institutionalized.

Organizational capability can be defined as the ability to consistently produce actions by the agents of the organization across a variety of situations that comply with organizational policies and procedures and further the goals of the organization. This is as true of private firms as not-for profit organizations (from religions to universities to hospitals) as for government agencies. This needn’t involve mimicking the organizational practices of private firms — it can be accomplished in a variety of ways

\footnotetext{
${ }^{9}$ In one meeting about accountability of government workers a member of the Planning Commission related the following story. The gardener at his government assigned housing in Delhi came to him to tell him that he would soon be getting a new gardener. When he asked his current gardener why he was leaving his job he got a quizzical look. His gardener patiently explained that he had been on contract, but as he had now been confirmed in a regular government post as a gardener he would obviously not be doing any more gardening and hence he would need a new contract person to do the gardening.
} 
from high powered incentives to fear and intimidation to rigorous selectivity to sustained inculcation of the organization's values (and likely some combination of all of the above). While organizational capability might be low because of low individual capability, the inability of the agents to correctly assess the situation and the appropriate response (e.g. doctors with too little training, under-educated engineers), low organizational capability can also be the result of weak organizations and a weak institutional environment in which the organizations operate. That is, the inability of organizations to hold its agents accountable, often due to institutional constraints beyond the control of the management of the organization (e.g. the high costs or impossibility of sanctioning any employee of the public sector), make accountability impossible.

Administrative modernism was one way of creating capable organizations in the public sector to carry out the range of functions required in a modern polity and economy from delivering the mail to teaching children to enforcing the law. While often criticized in advanced modern economies (for whom "bureaucracy" is a criticism and the "post office” a synonym for an antiquated organization) administrative modernism is a distant dream in today's India.

\section{III) Looking to the Future}

...the government, at every level, is today not adequately equipped... to meet the aspirations of the people. To be able to do so, we require the reform of government and of public institutions ... No objective in this development agenda can be met if we do not reform the instrument in our hand with which we have to work, namely the government and public institutions.

Prime Minister Manmohan Singh, June 24, 2004

I can hardly claim originality in pointing out the depth of the problems with government administration in India. The current Prime Minister, who is not a 
professional politician but rather a technocrat long engaged in policy making in India, has emphasized that improving implementation is a key constraint on achieving goals, and made progress in this reform an area of emphasis in his first major speech as Prime Minister. But there is today perhaps even less consensus about the direction forward on this front than in 2004 and, while many promising initiatives are underway, the way forward is at best murky. Neither, as an economist, can I claim disciplinary expertise and I worry that this essay will be like Robert Solow's characterization of growth theory, begin in empirics and end in a "blaze of amateur sociology.” Yet Robert Solow also taught me that "just because the tire is flat does not mean the hole is on the bottom." There is little question that, while the symptoms are manifest in administrative failure, this does not mean administrative reform is the cure. The nest two subsections speculate on the root causes (especially as compared to China) and possible future trajectory.

\section{III.a) Roots of the failure of administrative modernism}

There is a substantial body of thought in India today that believes that it is the way in which democracy has evolved in India that has undermined, rather than strengthened, administrative modernism in India. Naresh Saxena, a former IAS officer who served in Uttar Pradesh, penned a note for the National Advisory Council at the time of the newly elected government (in 2004) that is breath-taking in its hard hitting honesty about the current state of affairs (particularly in North India) and which articulates a common view within the elite civil service that things are going downhill, in large part because the integrity and non-partisan character of the civil service have deteriorated. As he says:

"...because between the expression of the will of the State (represented by politicians) and the execution of that will (through the administrators) there cannot be 
any long-term dichotomy. In other words, the model in which the politics will continue to be corrupt, casteist and will harbor criminals where as civil servants will continue to be efficient, responsive to public needs and change agents cannot be sustained indefinitely. In the long-run political and administrative values have to coincide."

In this view, the long-term dynamic of a steady deterioration of the Congress Party's role as an "encompassing interest” and institutionalized political aggregator from the grass roots, the rise of regional parties, and especially the rise of caste based parties have resulted in a politics that is detached from delivering the broad based benefits to citizens and more focused on jobs and contracts for their supporters and actively leads to a deterioration in administrative functioning ${ }^{10}$.

But as Pratap Bhanu Mehta has pointed out in his insightful essay, The Burden of Democracy, the simplistic attribution of the problem to bad politicians begs the question, as those willing to take the role of bad politicians are in abundant supply in every country. Rather, one must seek the root cause of the ability of bad politicians to survive and thrive in a very competitive electoral environment. In India, unlike in the US, there is a massive anti-incumbency bias in elections so one cannot explain the poor performance of democracy is facilitating administrative effectiveness as the result of “entrenched” politicians — they are not entrenched but must fight elections on an open and level playing field. One cannot blame politicians for trying to win elections. The question is, how are politicians winning elections while the government apparatus is weak?

A likely answer is that politics is an arena not just for competing for some neutral notion of government efficacy or even about a set of “policies” but is also a space for

\footnotetext{
${ }^{10}$ Again, Saxena (2004) puts it bluntly: “The political system in many states is accountable not to the people but to those who are behind the MLA; these are often contractors, mafia, corrupt bureaucrats, and manipulators who have made money through using the political system and hence are interested in the continuation of the chaos—and patronage based administration.”
} 
contestation over identities ${ }^{11}$. Perhaps the root issue with the flailing of administrative modernism in India today is the as yet unresolved (especially in the North) issues of identity politics around caste and communitarian concerns ${ }^{12}$. Up to a point, politicians have been able to survive on creating identities around caste and religion claiming to deliver social justice by the very fact of their election. That is, that someone of their group holds high office in and of itself provides social legitimacy to a group’s claims to fully equal participation in the social and political sphere. As one infamous Bihari politician, Lalu Prasad, put it, "people should have their dignity first, roads and bridges and other facilities can come later.” For groups for whom the election of politicians who shared their identity represented a public symbol of their own personal and identity claims to equal treatment in the social and political sphere at the local level, attacks on these politicians for a lack of effectiveness or corruption could be seen as, at best, missing the larger social point and at worst, as a retrograde attempt of the forces of the elite to "keep them in their place.” While Gandhi and Nehru are more widely known in the West, it is the actual or rumored desecration of a statue of Ambedkar can create deadly riots even today ${ }^{13}$.

The comparison with China is striking in this regard--it has long been remarked that China is "all state, no society” while India is "all society, no state.” The social heterogeneity of India at all levels, from different language groups in states to village level differences in religious and caste identity may make it much more difficult for

\footnotetext{
${ }^{11}$ I would like to thank Adarsh Kumar with helpful conversations on this section.

${ }^{12}$ The Southern states, particularly Kerala and Tamil Nadu followed a distinct evolution of caste politics, with these forces playing out much earlier, a factor to which some attribute their superior performance on some measures. However, it is worth pointing out that even these states are far from adequately performing, in a number of dimensions.

${ }^{13}$ The fact my Microsoft Word spell checker recognizes Gandhi and Nehru but red-lines Ambedkar makes my point about name recognition.
} 
administrative modernism to take hold as it is impossible to separate seeming "technical" questions about eligibility for government programs from social identity. Recent research examined the transcripts of the Gram Sabha (local village council) meetings that are intended to discuss and ratify various issues. The bulk of the discourse did not involve appeals to a common public weal or shared understanding derived from discourse but rather identify based claims (Ban and Rao 2008, Rao and Sanyal 2009). .

Of course even to the economist, the historical legacies of India versus China are an obvious source of difference in administrative effectiveness. Woodside's Lost Modernities (2004) points out that many of the key features associated with a "modern" civil service (e.g. merit based recruitment) existed in China and Korea hundreds of years before they emerged in the West. And as Whyte points out in this volume China had hundreds of years of experience as a "bureaucratic empire" with cultural and political unity.

\section{III.b) Consequences and relation to the economy}

One question that naturally arises is, if indeed, India is a flailing state, how is it that its economy has managed to grow so fast for so long? This is a particularly stark contrast with China where, although there is no question there has been some moves towards a more market oriented approach, there is also no question that the government has taken a very much leadership and controlling level and state engagement has been massive. It would take me far too far off topic to address the question of the overall sources of economic growth, which needless to say, the relative roles of government leadership and liberalization have been hotly debated by the world and India's premiere 
economists (e.g. Rodrik and Subramanian 2004, Panagariya 2008, Acharya 2006). But three comments of the relationship with a "flailing state" are possible.

First, India, while it is has grown very rapidly is still at very low absolute levels (roughly a third the PPP income of a middle income country like Mexico for instance)— so while it may take higher levels of government/state capability to reach middle income status, it is not impossible to grow from very low levels of income even with very weak governance. India’s neighbors with even weaker governance, such as Bangladesh, are proving that for sustaining economic growth one only needs "good enough" governance and, while governance has been "good enough" so far, it is an open question how much further India can go without a more capable state.

Many of the reforms undertaken over the last decades were "administrative capability saving” reforms in which the state simply stopped trying to do what it was flailing to do anyway. This type of reform can be win-win in that the government efforts are not effective at accomplishing their policy objectives but do create an inhibiting force on private sector efforts through inducing policy implementation uncertainty (HallwardDriemer, Khun-Jush and Pritchett 2009). The question is not whether or not India should have an industrial policy or activist state, but what kind of actions should be put on the agenda given the state's actual capabilities for implementation.

Second, on the level of proximate causes of economic growth, it is arithmetically capital(s) accumulation, the efficacy of that capital, and growth in overall productivity that account for growth. India has managed to maintain high levels of savings and investment—not nearly as high as China's, but respectable nonetheless. This is in part because the elite institutions of economic policy are much less susceptible to "flailing" 
than are the activities that require large scale implementation. So monetary policy has been more effective at containing inflation than, say, clinics have been at creating health. And, many of the post 1991 reform actions that have sustained rapid growth have been state capability economizing-by reducing the need for a government agency to improve all investments for instance-so that the efficacy of the state is less of a concern.

Third, the relative weakness of the Indian state in implementation capability has also affected the pattern of economic growth. A good rule of thumb is that in a desert one should expect to find camels not hippos (a phrase due to Ricardo Hausmann as part of growth diagnostics), that is, the firms that thrive will be those adapted to the local environment. The growth of the outsourcing industry is an obvious case in point. It is not that this industry was not affected by the government policy, it was that thrived on the things the government did well (e.g. the elite IIT graduates) and essentially cocooned itself from reliance on any government provided infrastructure services. So, while there is no definitive proof, it is a plausible conjecture that at least some part of the huge difference between China and India in success in manufacturing and manufactured exports is due to the paucity of infrastructure in India as compared to China (World Bank 2005).

\section{III.C) Future}

If this view, that the failure, so far, of the forms of political and administrative modernism to deliver the benefits of effective government is the result of unresolved issues of social identity that are playing out in the political and administrative spheres, is correct, what of the future? Is it bright or dim? Allow me make three comments, while 
acknowledging that if there is substantial contestation about the past and present one can hardly expect greater certainty about the future.

Lessons from history? It is difficult to know how to use the history of the emergence of administrative modernism in the late $19^{\text {th }}$ and early $20^{\text {th }}$ century USA or Europe (or its accelerated adoption in Japan under the Meiji) to understand how to proceed with administrative reform in India, as one suspects that one will fall victim to the fate predicted by Hegel (via Marx) that history will repeat itself the second time as farce. In the USA the modern administrative structures—-from the army to schooling to police forces—-were not transplanted but rather emerged organically from earlier attempts of citizens to establish services for themselves in a variety of contexts. What was new in the historical evolution was not the carrying out of the function but rather the new form. For instance, the modern administrative structures of schooling were the result of a consolidation and gradual regularization of pre-existing schools under local control. This meant that often the new formal structures of administration inherited informal mechanisms of social control and external accountability that were operating in the background while the administrative regimes were consolidating. In contrast, India today inherited its basic administrative structures wholesale from a colonial period in which the primary purposes of the administration machinery were not particularly developmental or service provision but maintaining order and extraction of revenues. They did not, one might say, emerge entirely organically from local soil.

This perspective puts the debates about decentralization to the Panchayat Raj Institutions (PRI) in a much broader context that merely debates about fiscal allocation rules or economies of scale and scope. As Rao (2005) argues there is a role of what he 
calls "symbolic public goods" and the way in which administration has been designed almost exclusively as vertical programs from the state or central level leaves little deliberative space for the creation of a sense of common purpose and destiny. Of course not even the most wild-eyed romantic should imagine that moving more decision making and responsibilities to the local level will immediately lead to better outcomes, rather the intent is to create a long-run process in which contestations in the political space are gradually transformed from contests of identity and recognition of the full equality of various groups into contests about the pragmatics of the operation of government.

Post modern is modern plus, not pre-modern. Many ideas about administrative reform are essentially "post-modern”- that is, are primarily aimed at improving on functional modernism. This is a complicated two-fold move against (and after) the triumph of the bureaucracy.

One element is the administrative reforms under the broad heading of "new public management" or "reinventing government" of the type implemented in the UK, New Zealand, parts of Australia and the USA in the 1990s. This was intended to make government more effective through an "autonomy for accountability" bargain in which bureaucrats were freed from onerous obligations to process ("red tape") in favor of more professional autonomy in achieving objectives. The counter-part to the increased autonomy was greater performance measurement and more accountability for results. As these are often regarded as "state of the art" administrative reforms there is a temptation to transplant these into a variety of settings. However, it is increasingly clear that moving to post-modern forms of governance rely just as much, or more, on the core of administrative modernism—it is not necessarily the case that if cannot do it yourself you 
can successful contract it out. Moving to the post-modern is not necessarily a solution to failed modernism.

A second element of the post-modern impulse is the softening of the hard edges of the Weberian bureaucracy through downplaying the notion of decision making through technical expertise and through emphasizing more “civic engagement” and “direct participation”- not just in the more purely political processes (which is to be expected) but in the process of administration itself. The advent of requirements for open public hearings in the making of regulatory decisions (which in the transition from pre-modern to modern would have been characterized as the exclusive province of the technician applying "scientific" notions or "neutrally" applying the law) is just one example. This is often supported through criticisms of the excesses of what James Scott refers to as “bureaucratic high modernism.” The work of Robert Putnam on the impact of "social capital” on the operation of democracy in Italy showed that, for all the claims to government bureaucracies were rules based organizations, even in a rich modern country like Italy the efficacy with which the mail was delivered was a function of how many singing clubs existed in the town. The social fabric mattered in important ways for the operation of quintessentially modern government organizations.

However, again, one can go overboard and attempt to lionize "social capital” as a replacement or substitute for functional modern organizations. Community participation and engagement in project and program implementation is very different thing if imagined as a post-modern reincarnation of pre-modern social ties as a substitute for an effective administration than if it is a post-modern supplement to the efficacy of existing institutions. 
Existing initiatives. India does not suffer from a dearth of proposals or initiatives for administrative reform nor from a lack of commissions (including of course an Administrative Reform commission). Nor even does it suffer from a lack of successful initiatives. Vikram Chand (2006) has documented more than a dozen case studies of successful initiatives in service delivery. However, the key question is why, if there is not dearth of initiatives, or even successes, things are not getting better at a more rapid pace. There are three generic issues that face the political economy of administrative reform.

First, a number of successful initiatives are the result of senior and powerful civil servants creating (or being given) political support and space to act as "reform champions" or "change agents.” They can then use their power within the administrative structure to initiate reforms. However, these reforms often prove fragile as they do not have a solid either popular base nor broad political buy-in. Hence a change in chief minister or even sectoral minister can bring reforms to a halt. This leads to the phenomena illustrated by Kapur (2006) of a life cycle of innovations (he illustrates it with institutional success) such that at any given time there are innovations being born, innovations maturing to scale (at the local or state level) but there are also reforms petering out and ending. If the reform death rate and birth rate are similar then there will always be a stream of reforms, but no forward progress. As long as the reforms are dependent on a particular civil servant (rather than politicians, who even with antiincumbency bias sometimes have a longer and more protected tenure in office) it is difficult for the reform to take hold. 
A second problem is that existing initiatives are always up against the powers behind the existing dysfunctions — whether it be the institutionalization of corruption, the patronage protection of civil servants or the contractors and their allies. There is a big difference between reforming a functional organization with problems and bringing a dysfunctional organization, in which the dysfunction has become the standard operating procedure for some time, back from the brink. When dysfunction has settled in, then there are settled expectations about future flows, which are often capitalized, and hence, paradoxically, people will oppose the fundamental fairness of reforms which they believe “expropriate” them. That is, at this stage, many positions, both political and civil service appointments are effectively auctioned off. The prices paid for positions depend on the anticipated take. Hence reforms that attempt to reduce the benefit of a position can be seen as taking away an asset they had purchased. This will be naturally be strongly resisted. How to dig one's way out of corruption that been "capitalized” and is semiopenly traded is a very difficult problem to which, to my knowledge, there is no research at all.

A final difficulty with mobilizing reform is that, in response to governmental dysfunction, people adopt coping mechanisms to provide the services in alternative ways. Once they have abandoned the public sector they have personal pecuniary interest in reform only if it allows them to return to the public sector. When, however, the potential gains from reform are small and uncertain it is difficult to mobilize a political coalition for reform, as it is often the potentially most powerful who have opted out first. Just as an example. Municipal water services have deteriorated in most Indian cities to the point that, even for those who have connections for piped water, the pipes are only pressurized 
for a few hours a day. In response to this, houses in the richer neighborhoods of Delhi have invested in an array of ways of coping - private wells, cisterns, storage tanks on the roof, etc. Once these expenditures are incurred, households do have 24/7 pressurized water inside their house. A recent study in Delhi showed that, in richer neighborhoods households spent more privately on water alternatives than their payments to the water corporation. Suppose now there is an initiative for reform that promises better service, say 24/7 water, but at higher than current cost (but lower than total public plus private coping expenditures). Do you support this? Probably not as the costs (higher bills) are immediate and the benefits are uncertain (what if the reform doesn't work) and in the future (when one would have had to replace the existing durable capital). These dynamics can lead into tipping point dynamics into a political vicious circle, beyond which one cannot assemble a majority (particularly a political power weighted majority) for reform because the threshold at which the typical household benefits is far from the realistic potential of reform improvement. This is already almost certainly true of ambulatory curative care (85 percent of visits private) and urban private schooling (in many states two thirds or more of children are in private schools).

Hirschman’s classic Exit, Voice, and Loyalty (1970) provides interesting insights, as individual responses to larger dysfunction of organizations, polities, or systems they participate in can either be to work from inside and try and improve them ("voice") or simply walk away and fulfill their needs in other ways ("exit”) ${ }^{14}$. In sector after sector the response to continued administrative flailing has been the exit into alternative service delivery modes: private schools for government, from surface irrigation to groundwater,

\footnotetext{
${ }^{14}$ While the title is widely known, the subtitle is equally important in this context: "Responses to decline in firms, organizations, and states."
} 
from water utilities to water vendors, from public clinics to private clinics. The combination of rising incomes and in some cases technological shifts (e.g. telephony, satellite TV) have allowed India’s elite an easy exit option, at least until a crisis hits.

The above does not mean that reform is impossible. It is just that it is not obvious whether one should go the route of "business as usual" reforms piecemeal in the hopes they scale or "game changing" reforms that create a different context and pressure for reform. For instance, how does one view the Right to Information act? On one level it is another in a string of attempts at piecemeal reform. However, in another light, it is an organizing principle of using information to create accountability, to create a groundswell of pressure, not just for the piecemeal addressing of individual concerns, but for broader reforms as the RTI is used to force larger number of issues onto the policy agenda in a way that mobilizes citizen constituencies around both general principles of improved governance as well as specific initiatives.

The role of ideas. While certainly entrenched interests are an obstacle to reform, perhaps the power and role of ideas should not be ignored. As Keynes argued, in the long run they may well be all that matter ${ }^{15}$. However, in this respect the role of ideas is itself something of a puzzle. It is difficult to summarize the intellectual zeitgeist of any country, particular one as complex as India, but the issues of government dysfunction seem to attract much less attention that one might expect given the otherwise vociferous and hugely "argumentative” (as Amartya Sen would have it) intellectual life in India. My impression from three years of living in India was that it was striking of how much of the

\footnotetext{
${ }^{15}$ As useful as the Marxist/Foucault notion that all ideas "super-structure" and/or are masks of power t o control discourse is in analyzing individual issues (a mindset that of course naturally appeals to all economists) it seems hardly compatible with the broad sweep of changes in ideas over the long $20^{\text {th }}$ century.
} 
intellectual discussion around policy and priorities looked entirely conventional, with the usual left-right splits about what the government "should” do, argued out, particularly among in the English language media I was exposed to, as if the government of India could do roughly whatever it was proposed they should do. The obvious and blatant facts of life to these same intellectuals: that their children were in private school, they used private health facilities, used agents for necessary interactions with the government, avoided the police (or paid bribes when stopped), relied on private coping mechanisms for water—-that is, coped with state dysfunction as best they could—never seemed to penetrate from the private sphere into debates about public policy. It seemed striking the extent to which advocacy of the "disadvantaged sections” nearly automatically translated into criticism of the market and advocacy of greater government action — even when the flailing incapability of the "business as usual" actions of the state has been amply documented. ${ }^{16}$

The major role played by leaders, not just as politicians in the conventional sense, but create a new vision in China (Mao) and India (Nehru) has been widely remarked. However, political parties in India seemed to have gone beyond the need to identify either efficacy or a particular ideology as legitimizing their power. As Mehta (2003) points out, no political party has made delivering effective services a major element of their platform. The risk is that the "right" settles into a "expect nothing, get nothing, try and pay nothing” alienation from all politics and the left continues as if the India, unreformed, could solve all ills if only sufficient resources were devoted to the social

\footnotetext{
${ }^{16}$ For instance, an interesting report by the Pratichi Trust about the state of education in West Bengal was particularly striking in documenting schools that were not just indifferent but actively hostile to students (with numerous accounts of physical abuse), one result of which was very low levels of learning achievement and a widespread recourse to tutoring. This of course in spite of teachers paid factor multiples of the existing wages for private sector teachers.
} 
problems, neither approach appears capable of generating the ideas base for a transformational social movement. .

\section{Conclusion}

Suppose a development expert from a modern, well-governed country, of today, say Norway, were told he was traveling to a foreign country but were really transported via a time machine to Chicago in 1929. He would find a booming economy, but corrupt politics, huge social tensions across races and ethnicities, vast economic inequalities, barely functional municipal services, unplanned and unregulated expansion of a city crowded with immigrants from rural areas and from other nations. What is his forecast? Should he be optimistic or pessimistic? What is his prescription? Where does one start with "reform" when everything seems out of control? From the hindsight of history, he should be optimistic, Chicago, while still perhaps far from being Norway, is a rich, vibrant, and functional city. But there was no magic bullet; change was a long, hard, slog. Corruption did not disappear overnight (or overmonth or overyear or overdecade). The police did not become less brutal and racist with one application of "reform."

I would have thought the experience with the collapse of the Soviet empire-in which neither the collapse itself nor the following events were accurately predicted-would have taught all experts that the only safe way to be prophetic is to be Delphic. Yet the theme of comparing "Rule and Reform" in India and China is too fascinating to resist, particularly as it appears that looking ahead China and India face almost polar opposite problems. As Alexander Woodside argues in Lost Modernities, many, if not most, elements of what I call "administrative modernism" were present in China at least by the 
Tang dynasty—almost 1400 years ago. The notion of “civil service” administration in which individuals chosen for their merit (not birth) by a competitive examination play a role in the implementation of policies is certainly very old and very respected in China. In contrast, China has little or no history or tradition of functioning democracy to call upon. The question for China is making the transition from authoritarian one-party control of the state and its functional administrative apparatus to some alternative means of political control of the state. Perhaps this is not a linear path to the "end of history" and the adoption of Western liberal democracy but something uniquely Chinese, but it is hard to believe that one-party rule survives for another fifty years.

India was born and has always lived in a democratic tradition, but has increasing weakness in the adoption of administrative modernism to its society and politics. To paraphrase Abraham Lincoln via Naresh Saxena, no government can long survive half democratic and half corrupt. India, with its multitude of reform efforts is struggling on the path to reforms that lead to the effective implementation of rules, but they are far from out of the woods.

What this produces is a combination of different uncertainties at different horizons. In India, one is deeply uncertain about the near future (and even, for that matter, about what is really happening in the present). But, as India’s formal political and administrative institutions are roughly those of many advanced nations, one can imagine India 50 years in the future without having had any major institutional shifts but having made a long hard steady slog to prosperity and governmental efficacy so long-run uncertainty is less. In contrast, in China one is very confident about the present-what the government says will happen will, with some slips twixt cup and lip, happen. But 
transitions in authoritarian regimes have, in many instances, been very problematic, and accompanied both in Chinese history and in recent practice, led to long interruptions in both economic and social progress so the long-run future of China is especially uncertain. 


\section{References}

Acharya, Shankar, 2006, Essays on Macroeconomic Policy and Growth in India/Shankar Acharya. New Delhi, Oxford University Press.

Anderson, Benedict (1983). Imagined Communities: Reflections on the Origin and Spread of Nationalism. London: Verso.

Ban. Radu and Vijayendra Rao, "Is Deliberation Equitable? Evidence from Transcripts of Village Meetings in Rural India," mimeo, Development Research Group, The World Bank. December 2008

Banerjee, Abhijit, Angus Deaton and Esther Duflo (2004). "Wealth, Health, and Health Services in Rural Rajasthan.” American Economic Review. 94:2, pp. 326-30.

Banerjee, Abhijit, Esther Duflo and Rachel Glennerster (2007) "Putting Band-Aid on a Corpse. Incentives for nurses in the Indian Public Health Care System.” Forthcoming Journal of the European Economics Association.

Bayly, Christopher (2003). The Birth of the Modern World, 1780-1914: Global Connections and Comparisons. Oxford: Blackwell.

Bertrand, Marianne, Simeon Djankov, Rema Hanna, and Sendhil Mullainathan. "Obtaining a Driving License in India: An Experimental Approach to Studying Corruption,” Quarterly Journal of Economics, November 2007, 122:4: 1639-76.

Chandler, A.D. (1977). The visible hand. Cambridge: Belknap Press.

Chandler, A. D. (1990). Scale and Scope: The Dynamics of Industrial Capitalism, Cambridge, MA, Harvard University Press.

Chaudhury, N. et al. (2006). "Missing in action: teacher and health worker absence in developing countries,” Journal of Economic Perspectives, 20(1) pp. 91-116.

Collier, David and Levitsky, Steven., 1997, Research Note: Democracy with Adjectives: Conceptual Innovation in Comparative Research, World Politics - Volume 49, Number 3, pp. 430-451

Das, Jishnu, and Jeffrey Hammer. (2005). "Money for Nothing: The Dire Straits of Medical Practice in Delhi, India.” World Bank Policy Research Working Paper no. 3669, World Bank, Washington, DC.

Duflo, Esther, Rema Hanna, and Stephen Ryan, (2008). “Monitoring Works: Getting Teachers to Come to School,” Cambridge, MA: National Bureau of Economic Research Inc. 
Ferguson, James (1994), The Anti-Politics Machine: “Development”, Depoliticization, and Bureaucratic Power in Lesotho. University of Minnesota Press.

Hirschman, Albert (1970), Exit, Voice, and Loyalty: Responses to Decline in Firms, Organizations, and States. Harvard University Press: Cambridge MA.

Mehta, Pratap Bhanu (2003). The burden of democracy. New Delhi: Penguin Books India.

Panagariya, Arvind, (2008), India: The Emerging Giant. Oxford University Press.

Rao, Vijayendra (2005). "Symbolic Public Goods and the Coordination of Collective Action: A Comparison of Local Development in India and Indonesia.” World Bank Research Working Paper no. 3685, Development Economics Research Group, World Bank, Washington, DC.

Rao, Vijayendra and P. Sanyal, 2009, "Dignity through Discourse: Poverty and the Culture of Deliberation in Indian Villages.” Mimeo (April).

Roberts, John, (2004), The Modern Firm. Oxford University Press: Oxford UK.

Rodrik, Dani and Arvind Subramanian, (2004), From Hindu Growth to Productivity Surge: The Mystery of India’s Growth Transition. CEPR Discussion 4371.

Saxena, N.C. (2005). "Improving Delivery of Programmes Through Administrative Reforms in India,” http://nac.nic.in/concept\%20papers/ncsimprovingdelivery.pdf.

Scott, James, (1998), Seeing Like a State: How Certain Schemes to Improve the Human Condition Have Failed. Yale University Press.

Swarup, Vikas, 2005, Q\&A. Scribner.

Woodside, Alexander, 2006, Lost Modernities: China, Vietnam, Korea and the Hazards of World History. Harvard University Press. 